\title{
28
}

\section{Experiments in restorative justice}

\author{
Heather Strang
}

\section{Introduction}

Restorative justice famously is a story both ancient and modern. It describes both the oldest means of nonviolent conflict resolution and the most recent framework for remedying long-recognised deficits in our criminal justice system. Its ancient form refers to traditional justice responses that entailed offenders making amends to their victims mainly through restitution, to restore order and peace after a conflict and to avoid the consequences of feud and vengeance (Weitekamp 1999). It remains pervasive in many different renderings throughout the world (Braithwaite 2002), but its lineage through the Pacific region has been especially important in the development of recent formulations of restorative justice. This history has been particularly significant in New Zealand and Australia, which, in large measure, have been the locations for many of the intellectual and practical developments in restorative justice (RJ) over the past 25 years.

In this chapter, I will discuss the recent history of RJ, especially in Australasia. I will describe the circumstances that led to both the establishment of a fledgling RJ program in Australia in the early 1990s and the events that saw that program become the subject of the largest piece of criminological research ever conducted in Australia. This research project, known as the Reintegrative Shaming Experiments (RISE), was based at The Australian National University (ANU) in 
the precursor to the Centre for Restorative Justice in the Regulatory Institutions Network (RegNet), and ran from 1995 until 2010 in its data collection phase, while data analysis continues to this day. I will discuss the setting up and running of this study, especially the collaborative arrangements for its conduct worked out between Canberra police officers and academics. Finally, I will assess the value of the RISE project today in the context of the growth of restorative practices worldwide.

\section{Definition and origins}

Today, the term 'restorative justice' covers a multitude of justice innovations that have taken place across the Western world over the past several decades. With roots in so many indigenous and preindustrial traditions of conflict resolution, new programs based on principles of reparation and reconciliation sprang into existence from the mid-1970s in North America in reaction to a widespread sense of dissatisfaction with the formal justice system, especially from the perspective of crime victims (van Ness 1986; Zehr 1990; Wright 1991). Victim-offender mediation (VOM) and victim-offender reconciliation programs have been used in limited areas of the United States since that time (Umbreit et al. 1994, 2000; Nugent et al. 2003), though without making serious inroads into mainstream criminal justice.

At the same time, European traditions of mediation in criminal matters going back many decades continued to flourish. This usually took the form of an out-of-court agreement between a victim and offender, sometimes but not always managed face-to-face and without other participants; in the case of 'shuttle mediation', a negotiator speaks with each party separately and attempts to reach a settlement that pleases all parties with no meeting at all. Meanwhile, by the late 1980s at the other end of the world, New Zealand was contemplating revolutionary changes to its justice system based on traditional Māori and Pacific Island conflict-resolution practices in which entire communities came together following disputes in which a member of one group had harmed a member of the other.

These disparate origins have led to a flowering of imaginative alternatives and additions to formal justice procedures and, at the same time, considerable confusion and disagreement about what constitutes the 
sine qua non of restorative justice. This confusion has led to the term encompassing a continuum from the crudest form of punitive payback through to the softest kind of resolution of trivial juvenile offending.

One way of addressing the definition problem in $\mathrm{RJ}$ is to describe it in terms of the way it works. The United Nations definition (UN 2002), for example, defines an RJ program as one that uses restorative processes and seeks to achieve restorative outcomes. Furthermore, a restorative process means:

any process in which the victim and the offender, and, where appropriate, any other individuals or community members affected by a crime, participate together actively in the resolution of matters arising from the crime, generally with the help of a facilitator. (UN 2002: 3)

More useful, perhaps, than this process orientation is Braithwaite's (2002: 14) proposal to focus on the content of RJ values. He suggests these should include respect for human rights specified in international human rights agreements, and notes that the principles found there include both emotional and material restoration after the harm caused by the crime. This broad view has the advantage of excluding categorically many programs that presently clutter the scene internationallythose that bear the 'RJ' label but which do not subscribe to these values.

Beyond these considerations, however, are some important aspects of the process itself without which the $\mathrm{RJ}$ label is, at the least, inappropriate. Indeed, it might be argued that process can sometimes trump values in deciding what is important in RJ (see Braithwaite and Strang 2001). Braithwaite's (2002) description of an RJ conference - the model that became the subject of the RISE program-usefully operationalises the values and the process:

Once wrongdoing is admitted ... the conference is a meeting of ... two communities of care. First there is a discussion of what was done and what the consequences have been for everyone in the room (the victim's suffering, the stress experienced by the offender's family). Then there is a discussion of what needs to be done to repair those different kinds of harm. A plan of action is agreed upon and signed by the offender and usually by the victim and the police officer responsible for the case. (Braithwaite 2002: 26)

These definitional difficulties in RJ have more than semantic importance. The looseness around what kind of justice intervention has the 'right' to be called RJ has led to problems with the interpretation of the 
body of research now available on the effectiveness of RJ as either a diversion from conventional justice or an addition to conventional justice (Strang and Sherman 2015). There have been many studies conducted on the effectiveness of some of these versions, but none that approaches the rigour of the RISE program, which was squarely focused on RJ conferencing as the model to be tested.

The Canberra RISE program has had enormous impact on RJ internationally as well as in Australia. The development of RISE and the significance of its findings for RJ worldwide are the themes of the remainder of this chapter.

\section{Restorative justice in Australasia}

The year 1989 was a critical one for RJ, though at the time few people could recognise it. It saw the introduction in New Zealand of the Children, Young Persons and their Families Act ${ }^{1}$ - a landmark piece of legislation that completely altered the principles and procedures for dealing with juvenile offending. It also saw the publication of Braithwaite's Crime, Shame and Reintegration. Neither of these mentioned the term 'restorative justice' and it is hard now to appreciate that the term was virtually unknown at the time. As Braithwaite (2002: 26) observed, at this time:

[F]or all of us, practice was ahead of theory, and it was well into the 1990s before the North American label 'restorative justice' subsumed what had been developing elsewhere for a long time.

But both these developments were fundamental to the establishment of restorative justice practices in the mainstream justice systems of Australia and New Zealand and, later, internationally.

Prior to the introduction of this new legislation, New Zealand had been struggling with a growing juvenile justice problem, especially in its indigenous communities (Maxwell and Morris 1993). Māori people especially were distressed about the increasing rate at which their young people were being arrested, charged and prosecuted through the courts and receiving custodial sentences in juvenile detention centres. They agitated for greater involvement of families in the resolution of offending behaviour, along traditional lines of resolving such matters

1 Available at: legislation.govt.nz/act/public/1989/0024/latest/DLM147088.html. 
(Power 2000). This legislation was a direct response to these concerns and led to the establishment of the New Zealand Family Group Conference (FGC) program.

FGCs were very much the model for a program set up in Wagga Wagga, New South Wales, in 1991 by NSW police officer Sergeant Terry O'Connell, following a visit he made to New Zealand. A colleague of his, John McDonald, an advisor on juvenile crime to the then NSW Police Commissioner, also visited New Zealand to observe FGCs. It was McDonald who read Braithwaite's Crime, Shame and Reintegration and recognised that this theory fitted both what he had observed in New Zealand and what was then being operationalised in Wagga Wagga. After many conversations and observations of O'Connell's RJ conferences, Braithwaite was convinced the program was robust enough both in its theoretical underpinning and in its execution to warrant the most rigorous evaluation of its effects.

By 1993, Braithwaite had embarked on an arduous journey both to gain the necessary permissions to expand the 'Wagga program' under the auspices of the NSW Police, whose officers would facilitate the conferences, and to raise funds for a rigorous evaluation of the program. As it turned out, getting the finance-difficult though it was to put together given the scale of the planned evaluation and the multiple funding sources-was a simpler affair to manage than the politics of policing at that time. After almost a year of negotiations, the NSW Police Commissioner, beset with difficulties of his own, declined to expand the program or to support the evaluation. Within a few days of this decision, however, the Australian Capital Territory (ACT) Chief Police Officer agreed to host a Canberra RJ conferencing program facilitated by ACT police officers, which would be the subject of the four RISE randomised controlled trials (RCTs).

\section{Setting up the RISE program}

Over six months in the first half of 1995, an RJ program, based on O'Connell's 'Wagga model', was set up in Canberra in collaboration with the Australian Federal Police and located inside the ACT Police. The fledging RISE research team taking shape in The Australian National University's Research School of Social Sciences Law Program at that time worked closely on the training of the police officers who 
would actually facilitate the RJ conferences that would be the subject of the RISE evaluation (see Strang 2012). We also planned and delivered information days to more than 600 operational officers across four major policing districts, both to familiarise them with $\mathrm{RJ}$ principles and practice and to explain the process by which they would be asked to refer eligible cases into RISE.

It was essential for every officer to understand the principles of randomisation and why treatment integrity was essential to the reliability and validity of the findings. It was only by engaging the cooperation of all these officers-if not always their enthusiasm-that cases could flow into RISE, because we depended entirely on them for referral into the study. As might have been anticipated, not all officers were interested in either the program or the evaluation, but the fact of such widespread exposure to RJ meant that, at the least, the term was familiar across the ACT Police Service and there was a high level of awareness of the kind of cases needed for referral into RISE.

The setting up and running of RISE involved establishing unusually close relationships between Canberra police and Canberra academics, which turned out to be a learning experience on both sides. As I have written elsewhere (Strang 2012: 214), successful research partnerships on the scale of the RISE program mean the cultivation of 'a set of human relationships and social networks between the research team and the leadership of the agency and the operational staff involved in program delivery'. This inevitably entailed multilayered understandings of the task in working towards a common purpose, often between individuals with little shared experience in their professional lives, yet all of whom could find satisfaction in what they accomplished jointly.

It was not only with the police that good relations were needed. In the months before the start of random assignment in July 1995, while a great deal of activity was under way with police training and while the finer details of the management of RISE were still be worked through, John Braithwaite and I embarked on a charm campaign across the ACT criminal justice system. No stone was left unturned in the magistrates' courts, across government departments and among both Crown prosecution and defence lawyers, especially those who worked in the Children's Court. We were not always warmly received. Canberra's defence lawyers, in general, were particularly defensive. They were concerned about the ethics of random assignment, they told us, and were especially concerned that juveniles would not have the benefit 
of their advocacy if they were diverted from court to RJ conferencing. They remained unconvinced of the wisdom both of the program itself and of testing RJ, throughout RISE.

Canberra's media proved another headache as we attempted to make both the RJ program and RISE itself better known to the Canberra community. They tended towards the view that RJ was another too-soft approach in dealing with juvenile crime, and wrote about it mostly in those terms. The Canberra Times was often at odds with us, with both its then crime reporter and its then editor taking a firm stand against our work, each for their own reasons. As for the public at large, RJ was largely unknown and they were generally indifferent to it.

\section{RISE research design and case referral}

From the outset, the objective of the RISE research team was to test the effectiveness of the RJ program in the most rigorous way possible, and with a variety of offenders and offences. RISE would therefore employ a randomised research design - the 'gold standard' for evaluation on the model of clinical testing of drugs and surgical procedures in medicine. The cases to be referred to the research team by the police were to be fed into a random assignment process that would decide whether eligible cases in the four offence categories would be dealt with in court (as they would normally be treated) or instead diverted to RJ conferences. It was agreed that these categories would be: juvenile offenders admitting property offences against a personal victim; juvenile offenders admitting shoplifting from large stores (no personal victims); offenders up to the age of 29 years admitting violent offences; and adults admitting drink-driving offences following a random breath test (see Strang 2002: Chapter 4 passim).

The inclusion in RISE of a large drink-driving experiment (900 cases) proved to be a useful way of communicating with the Canberra public at large about RISE. By their nature, random breath tests (RBTs) are indeed random and scoop up a random sample of Canberrans, or at least of Canberra drivers, and ACT police officers were conducting more than 100,000 RBTs each year. Every offender was required to bring supporters to the conference-in the case of drink driving, five supporters were expected-and it was estimated that more than 3,000 people had direct experience of $\mathrm{RJ}$ this way. 
The drink-driving experiment gave the research team a steady stream of cases and we were able to complete data collection for this offence within two years. By contrast, it took five long years to obtain enough cases in the other three experiments, with far more modest numbers sought. In that period, police officers referred 173 juvenile property cases, 113 juvenile shoplifting cases and 100 youth violence cases. This was not a huge haul, and many cases that would have been eligible for RISE were never referred for reasons briefly discussed below. Nevertheless, it was a large enough number of cases to reach robust and valid conclusions on the major outcome measures we specified.

The process of case referral from apprehending police officers to the research team now seems crude, but, at the time, it was cutting edge. It entailed providing every police officer with the RISE 'hotline' number to a mobile phone (radically new technology for the time) in the custody of a member of our core research staff on a rostered basis 24 hours a day, seven days a week, for the five-year life of the experiment. Officers had been trained about the type of cases we wanted in RISE; they also knew that they were by no means compelled to give us all such casesonly those they were comfortable about processing either by court or by conference.

The concept of random assignment is by no means an intuitive concept and proved a particularly tricky one with officers for whom certainty about the way to proceed in any given case was essential in many ways to their identity as police. But this research design was fundamental to the evaluation: none of us in the RISE team was interested in undertaking anything less rigorous and the advantages of an RCT were self-evident to us for establishing whether a causal relationship existed between the treatment and the outcomes. But the question of the ethics of random assignment often proves problematic in the operational environment (Strang 2012). For the research staff, it was easy to divide the ostensibly eligible cases into those that must go to court and those for which court or diversion to $\mathrm{RJ}$ were equally appropriate, given that we were in a condition of equipoise about the relative effectiveness of each in reducing reoffending: we simply could not tell which was better. For police officers whose culture and training were all about certainty, the number of cases were relatively few for whom they were willing to suspend that certainty and leave it to the sealed envelope held by the research team to decide which way they would be treated. 
The slow trickle of cases referred by the police caused the research team to come close to despair on occasion, as we struggled with the perennial problem when conducting experiments: case flow, case flow, case flow. Although much has been written about this issue (see, for example, Boruch 1997; Strang 2012), nothing prepared the RISE research team for such a lengthy and drawn-out data collection period-not to mention the additional funding needed to keep RISE going.

Throughout these five years, the research team kept up relentless contact both with senior police officers and with junior officers throughout the ACT. While any kind of tangible encouragement-even cakes and biscuits—was frowned on by senior police management, we put great effort into maintaining good personal relations with all officers. This proved to be the most reliable way of getting case referrals, although, inevitably, most of them ultimately came to us from a small number of committed officers.

At the planning stage, outcome measures were very much focused on offenders and especially the potential of RJ to reduce offending, given the preoccupation of government and the public with this goal of criminal justice policy. Nevertheless, it was agreed that, as well as the question of reoffending, there should be two other major outcome measures in comparing $\mathrm{RJ}$ and court treatment. The impact of $\mathrm{RJ}$ on participating victims was a focus of interest to the research team from the outset, even if at this early point victims' views were additional rather than a priority (but see Strang 2002). As well, we recognised that RISE presented an ideal opportunity to add to a growing theoretical and empirical evidence base on perceptions of both victims and offenders about procedural justice and police legitimacy as vital aspects of effective criminal justice (see, for example, Tyler 1990; Tyler et al. 1997; Sunshine and Tyler 2003).

The views of both victims and offenders in the RJ conferences and in court were sought via face-to-face interviews. This was a major logistical exercise, with over 60 interviewers involved in the first wave of interviewing alone, conducted within six to eight weeks of the finalisation of the case. Ultimately, two more waves of interviewing took place, two years and then 10 years after random assignment, each bringing its own set of problems in tracking down participants in the experiment and persuading them to be interviewed. 
In addition to the program of interviewing, the RISE team aimed to observe every court case and every RJ conference for the offenders in the experiment. This also required numerous staff members, not only to make and record the observations, but also to keep track of the numerous court appearances and the often complicated processes for setting up the conferences. In addition, we attempted to interview every offender and every victim and many of the supporters of both in every case. RISE must sometimes have seemed to its ANU colleagues like an enormous cuckoo in the nest, employing not only a core research team but also trailing a small army of ancillary observation and interview staff. At its peak, RISE consisted of around 10 observers and 20 interviewers working with the core team of five, who managed both ongoing collaboration with the police and courts and the enormous amount of data being generated.

Even as data collection continued with the addition of new cases into the experiment, from 1997 onwards, a parallel program of data collection began that entailed the re-interviewing of RISE offenders and victims two years after their initial random assignment. The purpose of these interviews was to assess the longer-term consequences of case disposal by court and by RJ conferencing.

Finally, a follow-up of both victims and offenders began in 2005 on the tenth anniversary of the first cases coming into RISE. This wave of interviewing tracked the intake of cases over the period 1995 to 2000, and the last of this third wave was completed in 2010.

\section{Impact of RISE in Australia and internationally}

Over the past 20 years, the RISE research team has published extensively on the findings of the experiments. The mass of data relating to findings gathered by observation of RISE cases disposed of both by court and by RJ conferencing, and by the interviewing of participants in those cases, is summarised in a major report published on the website of the Australian Institute of Criminology (Strang et al. 2011).

Results concerning reoffending patterns among offenders in the four RISE experiments, in all their complexity, have been reported elsewhere (see Sherman et al. 2000; Sherman and Strang 2007, 2012; Strang et 
al. 2013), but, in brief, the following claims can be made without equivocation about the effects of RJ compared with court over the two years following disposition:

- The juvenile/youth violence experiment showed that RJ reduced reoffending significantly more successfully than did court.

- The juvenile property experiment showed that, across all offenders, court reduced reoffending significantly more successfully than did RJ. This was due to the dramatic backfiring effect of RJ with Aboriginal property offenders; for white offenders, there was no significant difference between court and RJ.

- The drink-driving experiment showed that court reduced reoffending better than RJ.

- Across all experiments there were significantly higher perceptions of procedural fairness among both victims and offenders whose cases were dealt with by RJ than by court.

- In both the property and the violence experiments, victims expressed much higher levels of satisfaction with RJ than with court (see Strang 2002).

These results were received both nationally and internationally with huge interest, providing at last, as they did, a rigorous assessment of the effects and effectiveness of RJ compared with the processing of these kinds of cases through the court in the usual way. RJ is now widely used throughout Australia, though predominantly for juvenile offenders admitting to minor crime; Larsen's (2014) report describes in detail the current situation in each state and territory.

Nowhere were these results more eagerly received, however, than in the UK Home Office, which was extremely interested in the potential in England and Wales of an initiative with a strong evidence base that successfully reduced violent offending. The new Blair Government, elected in 1997 with a promise to be 'tough on crime, tough on the causes of crime', was putting substantial resources into crime research, with special attention given to RJ. Funding was made available for a series of follow-up experiments in the United Kingdom with a focus on the effects of RJ on violent crime. But, this time, eligible offenders were to be mostly adults, and RJ was not to be tested as a diversion from normal justice through the courts but, instead, as an addition to it. 
In 2001, members of the RISE research team were successful in winning the Home Office funding to undertake this research. The reach was much greater, however, encompassing eight experiments in different locations, with different kinds of offences and offenders with different levels of seriousness. This time the team concentrated on the development and management of the experiments, rather than purely on program evaluation, which was to be carried out independently by the University of Sheffield. Our operational partners were the London Metropolitan Police for the robbery and burglary experiments, the Northumbria Police for the property and violence experiments and prisons and probation authorities in the Thames Valley area of southern England for the experiments on the most serious violence cases.

These experiments took place between 2001 and 2004 and have been extensively reported on by the Sheffield University team (Shapland et al. $2006,2007,2008)$. They revealed, across all the experiments combined, a 27 per cent reduction in reoffending for offenders who experienced RJ in addition to normal justice processing, compared with those offenders randomly assigned not to receive RJ. It indicated as well that it was most effective for serious crime and appeared more effective for adults than for juveniles. In addition, there were exceptional levels of satisfaction among participating victims, with the additional benefit of significant reductions in post-traumatic stress symptoms among victims who had met their offenders in an RJ conference compared with those who had not had this experience (Angel et al. 2014).

Restorative justice conferencing now has the benefit of more numerous and more rigorous evaluations than perhaps any other criminal justice program. Some might say the world of RJ practice has been little influenced by this long program of research, bedevilled as it is by the cautiousness of policymakers around the Western world about applying it to those very cases for which research shows it to be most effective. Thus, RJ is still rarely used for serious and violent crime (but see, for example, Strang 2014) and instead is usually implemented precisely for those cases where evidence shows it to be least effective and sometimes even counterproductive: trivial offending by juveniles. Governments these days are unwilling to pay for additional services of the kind that RJ repays so well and instead tend to focus on using RJ practices as an alternative to more expensive criminal justice procedures. At the same time, a not infrequent consequence of these policies is net widening, with many additional lawbreakers, especially juveniles, being brought 
into the justice system in cases that would not have been proceeded with when so-called 'restorative practices' were not available (see Strang and Sherman 2015).

Nonetheless, the RISE team that gathered at ANU in 1995, and continued their work in RegNet's Centre for Restorative Justice, has much to be proud of. Nelson Mandela, on the occasion of his receiving an honorary Doctor of Laws at ANU in September 2000, inscribed his name on the sign for the centre-an inspiring moment for the team and a wonderful endorsement of our work. The quality and integrity of this long program of research are exceptional and the findings far-reaching. RISE, as well as the high-calibre research in the United Kingdom that built on it, is available for the world to see whenever scholars and practitioners need rigorous evidence about what $\mathrm{RJ}$ conferencing really can do.

\section{Further reading}

Strang, H 2002. 'Conclusion: Emerging practice and future directions', in J Bolitho, J Bruce and G Mason (eds), Restorative Justice: Adults and Emerging Practice. University of Sydney Institute of Criminology Series No. 30. Sydney: Institute of Criminology Press, pp. 231-9.

Strang, H 2012. 'Conferencing and victims', in E Zinsstag and I Vanfraechem (eds), Conferencing and Restorative Justice: International Practices and Perspectives. Oxford: Oxford University Press, pp. 83-100.

Strang, $\mathrm{H}$ and Braithwaite, J (eds) 2002. Restorative Justice and Family Violence. Cambridge: Cambridge University Press.

\section{References}

Angel, C, Sherman, L, Strang, H, Ariel, B, Bennett, S, Inkpen, N, Keane, A and Richmond, T 2014. 'Short-term effects of restorative justice conferences on post-traumatic stress symptoms among robbery and burglary victims: A randomised, controlled trial', Journal of Experimental Criminology 10(3): 291-307. doi.org/10.1007/ s11292-014-9200-0. 
Boruch, R 1997. Randomized Experiments for Planning and Evaluation. Thousand Oaks, CA: Sage. doi.org/10.4135/9781412985574.

Braithwaite, J 1989. Crime, Shame and Reintegration. Cambridge: Cambridge University Press. doi.org/10.1017/CBO9780511804618.

Braithwaite, J 2002. Restorative Justice and Responsive Regulation. Oxford: Oxford University Press.

Braithwaite, J and Strang, H 2001. 'Introduction', in H Strang and J Braithwaite (eds), Restorative Justice and Civil Society. Cambridge: Cambridge University Press, pp. 1-13.

Larsen, J 2014. Restorative justice in the Australian criminal justice system, Research and Public Policy Series 127, Australian Institute of Criminology, Canberra.

Maxwell, G and Morris, A 1993. Families, Victims and Culture: Youth Justice in New Zealand. Wellington: Social Policy Agency and Institute of Criminology, Victoria University of Wellington.

Nugent, W, Williams, M and Umbreit, M 2003. 'Participation in victimoffender mediation and the prevalence and severity of subsequent delinquent behavior: A meta-analysis', Utah Law Review 2003(1): 137-66.

Power, P 2000. Restorative conferences in Australia and New Zealand, $\mathrm{PhD}$ thesis, Law School, University of Sydney, Sydney.

Shapland, J, Atkinson, A, Atkinson, H, Chapman, B, Dignan, J, Howes, M, Johnstone, J, Robinson, G and Sorsby, A 2007. Restorative Justice: The Views of Victims and Offenders. The Third Report from the Evaluation of Three Schemes. Research Series 3/07. London: Ministry of Justice.

Shapland, J, Atkinson, A, Atkinson, H, Colledge, E, Dignan, J, Howes, M, Johnstone, J, Robinson, G and Sorsby, A 2006. Restorative Justice in Practice: The Second Report from the Evaluation of Three Schemes. Sheffield: Centre for Criminological Research, University of Sheffield. 
Shapland, J, Atkinson, A, Atkinson, H, Dignan, J, Edwards, L, Hibbert, J, Howes, M, Johnstone, J, Robinson, G and Sorsby, A 2008. Does Restorative Justice Affect Reconviction? The Fourth Report from the Evaluation of Three Schemes. Research Series 10/08. London: Ministry of Justice.

Sherman, L and Strang, H 2007. Restorative Justice: The Evidence. London: Smith Institute.

Sherman, L and Strang, H 2012. 'Restorative justice as evidence-based sentencing', in J Petersilia and K Reitz (eds), The Oxford Handbook of Sentencing and Corrections. New York: Oxford University Press, pp. 215-43. doi.org/10.1093/oxfordhb/9780199730148.013.0009.

Sherman, L, Strang, H and Woods, D 2000. Recidivism Patterns in the Canberra Reintegrative Shaming Experiments (RISE). Canberra: Centre for Restorative Justice, The Australian National University. Available at: www.aic.gov.au/criminal_justice_system/rjustice/rise/ recidivism.html.

Strang, H 2002. Repair or Revenge: Victims and Restorative Justice. Oxford: Oxford University Press.

Strang, H 2012. 'Coalitions for a common purpose: Managing relationships in experiments', Journal of Experimental Criminology 8(3): 211-25. doi.org/10.1007/s11292-012-9148-x.

Strang, H 2014. 'Conclusion', in A Hayden, L Gelsthorpe, V Kingi and A Morris (eds), A Restorative Approach to Family Violence: Changing Tack. Farnham, UK: Ashgate, pp. 221-30. doi. org/10.1057/9781137338082.0010.

Strang, H and Sherman, L 2015. 'The morality of evidence: Second annual restorative justice lecture', Restorative Justice: An International Journal 3(1): 1-15. doi.org/10.1080/20504721.2015.1049869.

Strang, H, Sherman, L, Mayo-Wilson, E, Woods, D and Ariel, B 2013. Restorative Justice Conferencing (RJC) Using Face-to-Face Meetings of Offenders and Victims: Effects on Offender Recidivism and Victim Satisfaction. A Systematic Review. Oslo: Campbell Systematic Reviews. Available at: campbellcollaboration.org/lib/project/63/. 
Strang, H, Sherman, L, Woods, D and Barnes, G 2011. Experiments in Restorative Policing: Final Report on the Canberra Reintegrative Shaming Experiments. Canberra: Regulatory Institutions Network, The Australian National University. Available at: www.aic.gov.au/ criminal_justice_system/rjustice/rise/final.html.

Sunshine, J and Tyler, T 2003. 'The role of procedural justice and legitimacy in shaping public support for policing', Law E Society Review 37(3): 513-48. doi.org/10.1111/1540-5893.3703002.

Tyler, T 1990. Why People Obey the Law. New Haven, Conn.: Yale University Press.

Tyler, T, Broeckmann, R, Smith, H, Huo, Y and Yuen, J 1997. Social Justice in a Diverse Society. Boulder, Colo.: Westview Press.

Umbreit, M, Coates, R and Kalanj, B 1994. Victim Meets Offender: The Impact of Restorative Justice and Mediation. Monsey, NY: Criminal Justice Press.

Umbreit, M, Coates, R and Roberts, A 2000. 'The impact of victimoffender mediation: A cross national perspective', Mediation Quarterly 17(3): 215-29. doi.org/10.1002/crq.3900170303.

United Nations (UN) 2002. Basic principles on the use of restorative justice programmes in criminal matters, ECOSOC Resolution 2002/12, 24 July, United Nations Economic and Social Council, New York. Available at: un.org/en/ecosoc/docs/2002/resolution\%20 2002-12.pdf.

van Ness, D 1986. Crime and Its Victims: What Can We Do? Downers Grove, Ill.: Intervarsity Press.

Weitekamp, E 1999. 'The history of restorative justice', in G Bazemore and L Walgrave (eds), Restoring Juvenile Justice: Repairing the Harm of Youth Crime. Monsey, NY: Criminal Justice Press, pp. 75-102.

Wright, M 1991. Justice for Victims and Offenders: A Restorative Response to Crime. Milton Keynes: Open University Press.

Zehr, H 1990. Changing Lenses: A New Focus for Criminal Justice. Scottsdale, Pa: Herald Press. 
This text is taken from Regulatory Theory: Foundations and applications, edited by Peter Drahos, published 2017 by ANU Press, The Australian National University, Canberra, Australia. 